\title{
Otázka proměny politických elit maloměst po rozpadu Rakouska-Uherska: př́ípady Uherského Hradiště a Brixenu
}

\author{
JAN ZAPLETAL* - MARKÉTA ZAPLETALOVÁ** \\ The Question of the Changes of Political Elites in Small Towns after the Dissolution \\ of Austria-Hungary: Cases of Uherské Hradiště and Brixen
}

\begin{abstract}
Using a micro-analytical approach, this case study attempts to capture and explain situation of local political elites in two comparable agrarian small towns from different parts of Habsburg Monarchy (Uherské Hradiště and Brixen) during crucial time of their transition from the Austrian rule to different conditions of new states after the WWI. We concentrate on social background and political and social attitudes of municipal elites, exposed to substantial pressures for adaptation emerging from deep contextual change with important national-political consequences and linked to democratisation and growing ideologization of political life. The two towns were determined to take a different path. Brixen was forcibly incorporated into a state with different history and culture and consequently faced establishment of Fascist regime. Political elites thus were confronted with until then unknown challenges. On the other hand, the transition to the own republican state represented a fulfilled dream for the citizens of Uherské Hraditě although local elites had to deal with the rise of new (educated) elites, new political parties and modern transformational processes. However, political-national fracture accompanied by modernising tendencies did not bring fundamental discontinuity in the position of municipal elites of both towns who were still able to maintain political and wider social influence.
\end{abstract}

Keywords: Agrarian small town; local political elites; break-up of Austria-Hungary; state and constitutional change

DOI: $10.14712 / 23363525.2020 .20$

\section{Úvod}

Předkládaná studie si klade za cíl postihnout a v souvislostech objasnit působení politických elit v agrárních maloměstech (Brixen, Uherské Hradiště) ${ }^{1} \mathrm{v}$ kruciálním období jejich přechodu z pod rakousko-uherské správy do odlišných podmínek nových států po I. světové válce. Předmětem zájmu jsou společenské zázemí, politické a sociální postoje místních elit, jež sehrávaly zásadní politicko-společenskou roli v rámci základních vývojových tendencí utváření politického a hospodářského života maloměst. Tyto elity byly ve

* Mgr. et Mgr. Jan Zapletal, Ph.D., Základní škola Uherské Hradiště, externí spolupracovník na Filozofické fakultě Univerzity Palackého v Olomouci.

* Markéta Zapletalová, Filozofická fakulta Univerzity Palackého v Olomouci, Křížkovského 511/10, 77147 Olomouc. E-mail: m.zapletalova@upol.cz

1 Vymezení zvolených sídel se opírá o frankfurtskou typologii, která města Brixen a Uherské Hradiště řadí do skupiny tzv. správních center se silnou vazbou na zemědělské zázemí, jež jsou charakterizována absencí velkých průmyslových podniků [Reulecke 1985: 46]. Vzhledem k dlouhodobému statusu Brixenu jakožto biskupského města můžeme v tomto př́padě hovořit rovněž o centru duchovně-agrárním [viz též Zapletal Zapletalová 2019]. 
zkoumaném období před a po I. světové válce vystaveny adaptačním tlakům vyplývajícím z výrazné kontextuální proměny spočívající primárně ve změně státoprávní se zásadními národnostně-politickými důsledky, jež se však zároveň prolíná s rychle postupující tendencí demokratizace politického života (zejména rozšiřování volebního práva) a rovněž jeho ideologizací nastupující v poválečném období.

Působení městských elit sledujeme ve dvou vybraných habsburských maloměstech z různých částí rozlehlé monarchie - jihotyrolském Brixenu a východomoravském Uherském Hradišti. Budou nastíněny zlomové momenty, které pro obě maloměsta znamenaly akcentaci změn $\mathrm{v}$ rovině společenské, politické i hospodářské. Zejména v komparaci s prameny z oblasti komunální volební agendy lze získat základní přehled o hlavních trendech sociopolitického vývoje ve městě a míře dopadu těchto změn do oblasti komunální správy a života. Volba srovnání případů Brixenu a Uherského Hradiště se pojí se širším záměrem zkoumat rozdíly či podobnosti vývoje a proměny elit agrárních maloměst v různých částech habsburské monarchie. Omezení studie na tato dvě typově podobná maloměsta z východní Moravy a Jižního Tyrolska je vedeno snahou o sledování dopadů zásadních tlaků způsobených proměnou státoprávního uspořádání, tj. začleněním do jiného/nového státu, a redefinicí národnostního kontextu, které v př́padě rakouských maloměst absentují. V italském Brixenu je daný tlak navíc záhy znásoben nástupem fašistického režimu s jeho zásahy jak ve sféře řízení komunální politiky, tak ve vztahu k neitalským menšinám.

Pojmem lokální politické elity ve zkoumaných maloměstech označujeme skupiny občanů, které lze vymezit několika základními atributy. Primárně jde o přímý vliv na výkon politické moci na lokální úrovni, tj. tito občané mají rozhodovací pravomoci jako členové obecních samospráv, zastupitelstev, rad a výborů, přičemž jejich politický vliv spojený s volenou funkcí se obvykle odvíjí od společenské prestiže a ekonomického statusu. Společenské postavení těchto lokálních elit je charakterizováno jistotou, která je dána zejména původem, majetkem, rodinnými a společenskými vazbami, jež tvoří základní předpoklady pro udržení vlastních pozic [srov. Schumann 1983: 30-38]. Obvyklé mnohoobročnictví, nepotismus a vzájemná provázanost napomáhají k zachování přímého i neprrímého/ neformálního vlivu na chod věcí veřejných, který posilují prostřednictvím aktivní účasti ve spolcích, zájmových skupinách a různých svazech. ${ }^{2}$ Tradiční maloměstské elity původně představovaly velmi úzký okruh, přičemž k jejich označení a terminologickému ukotvení přistupuje středoevropská historiografie odlišně. V rakouském kontextu je pracováno s politickým vymezením na „staré, tj. konzervativní, a „nové, chápané jako liberální. Zatímco „staré“, nebo také honorační elity v maloměstech na konci 19. století spojujeme se zájmy bohatých měštanských rodin, „nové“ elity byly představiteli původně méně majetných vzdělanostních skupin, vytvářejících postupně vysoce kvalifikovanou maloměstskou vrstvu [srov. Bösch 1992: 39]. Vztahy obou skupin byly ovlivněny postupujícími procesy modernizace, které jednak přinášely nové rozšířené možnosti sociálního vzestupu, a jednak spolupůsobily při jejich vzájemném provázání [Stekl - Urbanitsch 2000: 471-472; Mosser 1980: 13-14]. ${ }^{3}$

2 Obvyklým př́kladem nepotismu v městských funkcích je rodinná linie otec-syn nebo tchán-zet' (tzv. Hochzeitsvater) [srov. Kladiwa 2004: 37]; k problematice tehdejší politiky obecněji viz [Malír 2000: 11-32, Weiser 2001: 9-21].

3 V české historiografii byla problematika vývoje městských elit spíše opomíjena a podceňována. To se v zásadě mění po r. 2000, kdy v rámci širších badatelských projektů zaměřených na vývoj municipalit dochází 
Působení maloměstských lokálních elit nás zajímá v prvé řadě v perspektivě jejich proměny, vývoje či (dis)kontinuity. Text se snaží nalézt odpovědi na otázky, zda a nakolik hluboký kontextuální přelom ovlivnil politicko-sociální působení a pozice lokáních elit. Můžeme hovořit o ústupu původních/dosavadních lokálních elit, anebo byly schopné se úspěšně adaptovat na nové podmínky? Je možné identifikovat nástup či dokonce převahu elit zcela nových, jejichž vzestup by byl rámován a definován dramatickými politickými změnami? Výsledky bádání zaměřeného na zkoumání proměny starých a nástupu nových (obvykle prríchozích) lokálních elit v souvislosti s modernizačními tendencemi na přelomu 19. a 20. století poukázaly jen na mírné posuny v jinak téměř statickém politicko-ekonomickém obrazu habsburského agrárního maloměsta. ${ }^{4}$ Maloměsta agrárního typu lze chápat jako „meziprostor“ [Jacobeit 1998: 315-339], kde místní finančně a majetkově saturovaná elita splývá s politickými elitami a zároveň také absorbuje nově př́íchozí vzdělané osobnosti. ${ }^{5}$ Zatímco tehdy zde převážila úspěšná kooptace „nových“ do prostoru, v němž stále přetrvávala dominance starých (honoračních) rodin, v př́padě zásadního politicko-národnostního zlomu v průběhu dalších dvou desetiletí by bylo v souvislosti s postavením lokálních elit možné očekávat výraznější diskontinuitu.

Procesy modernizace přinášející změny v obou sledovaných maloměstech začaly probíhat v posledních dvou dekádách 19. století. Brixen se začal modernizovat již v 80. letech 19. století, Uherské Hradiště o desetiletí později poté, co radnici ovládli Češi. Tím dochází k částečné proměně elit a sociálních skupin, zároveň se mění ekonomické postavení obchodníků a živnostníků. Následkem změn, v Brixenu za éry Otto von Guggenberga (1903-1913) a v Uherském Hradišti za starostování Josefa Stancla staršího (1896-1903 a 1906-1912), dochází k parciálnímu rozpuštění tradičních sociálních vztahů. V Brixenu si tradiční elity udržovaly vysokou společenskou prestiž v městské společnosti. Jejich činnost v obecní radě jim zajištovala kontakty a informace, protože obecní volby nebyly výsledkem stranické prŕíslušnosti, ale odrážely ekonomické mocenské pozice a společenský status

k souhrnu dosavadního výzkumu a jsou publikovány klíčové práce. Komunální politika v širším smyslu začala být zkoumána jako místo, kde se neustále střetává politika s občanskou angažovaností. Vedle v textu uvedených prací viz rovněž Kladiwa, Pavel - Pokludová, Andrea - Kafková, Renata [2008]. Lesk a bída obecních samospráv Moravy a Slezska 1850-1914, II. díl, 1. svazek. Muži z radnice. Ostrava: Filozofická fakulta Ostravské univerzity; Fasora, Lukáš - Hanuš, Jiří - Maliř, Jiří (ed.) [2006]. Občanské elity a obecní samospráva 1848-1918. Brno: CDK; Pál, Judit - Popovici, Vlad (ed.) [2014]. Elites and Politics in Central and Eastern Europe (1848-1918). Frankfurt am Main: Peter Lang; Schmidt, Jürgen [2005]. Begrenzte Spielräume. Eine Beziehungsgeschichte von Arbeiterschaft und Bürgertum am Beispiel Erfurts 1870 bis 1914. Göttingen: Vandenhoeck \& Ruprecht; Kladiwa, Pavel - Zářický, Aleš (ed.) [2009]. Město a městská společnost v procesu modernizace 1740-1918. Ostrava: Ostravská univerzita; Růžička, Jan [2016]. Maloměštáci s otevřrenou myslí: Obecní reprezentace Bučovic a Slavkova (1850-1914). Brno: Matice moravská; Haas, Hanns - Hiebl, Ewald (ed.) [2007]. Politik vor Ort. Sinngebung in ländlichen und kleinstädtischen Lebenswelten. Innsbruck - Wien Bozen (Jahrbuch für Geschichte des ländlichen Raumes); Zimmermann, Clemens (ed.) [2003]. Kleinstadt in der Moderne. Ostfildern: Thorbecke, zde zejména zobecňující studie Heiss, Hans - Hannes Stekl: Bürgertum und gesellschaftliche Modernisierung in Österreichs Kleinstädten 1850-1914, s. 87-118, navazující na předchozí výzkumy.

4 Viz např. předchozí studie autorů [2019: 347-380] Nové politické elity maloměst na přelomu 19. a 20. století, v níž byla pozornost zaměřena na otázku proměny maloměstských politických elit v šesti habsburských agrárních maloměstech z různých zemí monarchie. Kromě v této studii sledovaných měst Brixenu a Uherského Hradiště byly zkoumány také východomoravský Uherský Brod a dolnorakouská města Horn, Eggenburg a Retz. Zde rovněž podrobněji k terminologicko-kontextuálnímu vymezení, na něž navazujeme.

5 Je to prostor „mezi městem a venkovem, stálostí a pokrokem, tradicí a vzděláním, cechovními výsadami a moderní profesionalizací" [Jacobeit 1988: 317]. 
volených. Městská elita obou maloměst sestávala především z dlouholetých, ekonomicky významných rodin a byla charakterizována specifickou adaptabilitou na hospodářský rozvoj od konce 19. století. Jednotliví řemeslníci, obchodníci či hoteliéři, se vyrovnávali s hospodářskými změnami často prostřednictvím investic do několika sektorů ekonomiky (např. Stanclova cihelna v Mařaticích u Uherského Hradiště). ${ }^{6}$ Kořeny poválečných samospráv se často nacházejí v maloměstském řemeslném a obchodním prostředí. Měštanská obchodní elita konkuruje a zároveň kooperuje s tradičními vrstvami. Hanns Haas ji nazval Zwischenmilieu, tedy tou, která se pohybuje „mezi městem a krajem, vytrvalostí a pokrokem, tradicí a vzděláním, privilegii a profesionalizací a „usazováním a mobilitou“ [Haas 1990: 264-265]. ${ }^{7}$ Možnosti př́slušníků této Zwischenmilieu byly, s ohledem na velikost kapitálu, relativně malé. Výroba, obchod a pracovní proces je stále do značné míry tradičně strukturován. Vzhledem k jejich velkému významu v místní politice však maloměstská obchodní elita v historických pramenech zanechala mnoho stop (jako Schwaighoferové v Brixenu či Schindlerové v Hradišti), kdy nadále v obecních radách a výborech vynikali před novými (příchozími) elitami. ${ }^{8}$

Tabulka 1: Přehled vývoje počtu obyvatel a národnostního složení

\begin{tabular}{|l|c|c|c|}
\hline Město/Rok & $\mathbf{1 9 0 0}$ & $\mathbf{1 9 1 0}$ & $\mathbf{1 9 2 1}$ \\
\hline Brixen $^{\star}$ & $5783(231)$ & $6542(190)$ & $5773(1500)^{9}$ \\
\hline Uherské Hradiště $^{\star *}$ & $5146(937)$ & $5174(369)$ & $5682(157)$ \\
\hline
\end{tabular}

${ }^{*} \mathrm{~V}$ závorce je uveden počet obyvatel italské národnosti.

** V závorce je uveden počet obyvatel německé národnosti (k židovské národnosti se v roce 1921 hlásilo 351 obyvatel) [Verbik - Zemek a kol. 1981: 392].

Zdroj: [Spezialortsrepertorium der österreichischen Länder 1910; Klein 2016; Gelmi 2000: 251-256; Heiss 2004: 223; Verbík - Zemek a kol. 1981: 330]

Tabulka 2 a 3: Přehled zastupitelských mandátů politických stran v obecních volbách

\begin{tabular}{|c|c|c|}
\hline Brixen & 1913 (30 zastupitelů) & 1922 (20 zastupitelů) \\
\hline Křest’ansko-socialistická & 15 & \multirow{2}{*}{16} \\
\hline Konzervativní & 8 & \\
\hline Německá liberální & 5 & 4 \\
\hline Svobodná občanská & 2 & - \\
\hline
\end{tabular}

Ke vzestupu „vesnického měštanstva“v maloměštanstvo srov. rovněž [Jacobeit 1988: 315-327].

Pro sociální dějiny, koncepce a terminologii Zwischenmilieu srov. [Frie 2004: 94-108; Haas 1990: 264-265].

Toto lze sledovat i u některých větších rakouských měst v prvních desetiletích 20. století, kdy příkladem může být hornorakouský Linec [viz Tweraser 1980: 328-330].

9 Brixen se za I. světové války změnil ve „vojenský lazaret“, kde nedostatek potravin a těžkosti masivně zvýšily úmrtnost. Spojení s Itálií v roce 1919 přineslo velké změny, kdy se př́liv italských vojáků a obyvatel promítl i do etnického složení. V r. 1918 Italové představovali jen 2,7 \% obyv. města, v r. 1922 již 26 \% [Gelmi 2000: $251]$. 


\begin{tabular}{|l|c|c|}
\hline Uherské Hradiště (36 zastupitelů) & 1919 & 1923 \\
\cline { 1 - 1 } Živnostensko-obchodní & \multirow{2}{*}{21} & 4 \\
\cline { 1 - 1 } Republikánská (agrární) & & 1 \\
\cline { 1 - 1 } Národní demokracie & 3 & 3 \\
\cline { 1 - 1 } Lidová židovská & 3 & - \\
\hline Pokroková realistická & 2 & 3 \\
\hline Národně socialistická & 3 & 2 \\
\hline Lidová & 3 & 3 \\
\hline Sociálně demokratická & - & - \\
\hline Komunistická & 1 & 1 \\
\hline Občanská skupina práce & - & 2 \\
\hline Německé pracovní a volební společenství & $1981 ; 382$ & \\
\hline
\end{tabular}

Zdroj: [SOkA UH k); Kasslatter 1988: 22-24; Verbík - Zemek a kol. 1981: 382-409]

\section{Brixen}

V jihotyrolském Brixenu nacházíme v mnoha ohledech příklad původního modelu biskupského maloměsta. Poté co v 19. století město ztratilo biskupský status, což vedlo k odchodu šlechty a úředníků, stalo se typickým provinčním maloměstem se silnou agrární strukturou a vlivnou církví, kde byly vztahy mezi měštany úzce spjaty s místní samosprávou [Flachenecker 1992: 394-404]. Politická atmosféra tu kolísala mezi konsenzy a konflikty přerůstajícími v hádky, v nichž jednotlivé skupiny prosazovaly vlastní parciální zájmy.

S přelomem 19. a 20. století začínaly být pozice konzervativců oslabovány rozšiřujícím se volebním právem. ${ }^{10} \mathrm{~V}$ tomto období dochází také k proměně přístupu místního semináře, jedné z nejznámějších teologických škol v celé Habsburské monarchii a pevnosti proti jakémukoliv druhu josefinismu a liberalismu, jenž se otevírá veřejnosti a stává se institucí křestanských sociálních idejí. Prudký rozvoj města nastal po porážce konzervativců a liberálů ve volbách v roce 1903, kdy se do čela samosprávy dostávají právě křest’anští socialisté [srov. Königsrainer 1995: 90-93; Schober 1993: 620-634]. Skončila doba „udržovací“. Na druhou stranu, místní elity musely postupovat tak, aby vzestup nepodtrhly neuváženými kroky, jež by výrazněji narušily existující vazby. Více se začalo investovat do městské infrastruktury a především lázeňství, které město proměňuje ve významné lázeňské centrum a oblíbenou odpočinkovou destinaci rakouské monarchie, jíž hojně navštěvovali i členové rozvětveného habsburského rodu. Nástup křestanských socialistů do vedení obce nejvýrazněji symbolizuje starosta Otto von Guggenberg, jehož politický styl se zcela odlišoval od dosavadních způsobů vedení politického boje a s jeho volebním vítězstvím dochází $\mathrm{k}$ intenzifikaci personalizace funkce starosty [Heiss 2004: 231-232].

Ihned po odchodu Guggenberga ze zdravotních důvodů v srpnu 1913 (umírá v r. 1914) však znovu propukají staré spory mezi stranami, stávající klid narušují konflikty a někdy

10 Např̀ v r. 1888 mohlo volit 10,5 \% obyvatel a v r. 1913 již 15,7 \% [srov. Kocka 1989: 13]. 
i násilné stř̌ety, které pak pokračují za I. světové války. Trvající konflikty měly za následek, že Brixen byl až do roku 1922 ř́zen městským výborem zvoleným v roce 1913, který se skládal z 30 zastupitelů a 15 náhradníků. Střety mezi politickými skupinami ohledně Guggenbergova nástupnictví zabránily plánovaným volbám obecního výboru, jež se měly konat $\mathrm{v}$ roce 1918. Vzhledem ke změněné politické situaci tak bylo rozhodnuto využít právní možnosti ponechat členy zvolené v roce 1913 ve funkci [Milesi 2002: 12].

Spory se výrazně vyhrotily na podzim 1913 kvůli starostenské volbě a politickému „veletoči“ hostinského Johanna Stremitzera, dlouholetého radního, více než dvacet let předsedy finančního výboru a blízkého spolupracovníka předchozího starosty, který byl starostou zvolen těsným poměrem 15:14 hlasům. Avšak nikoliv za křestanské socialisty, ale jako kandidát konzervativců a liberálů. Johannovi Stremitzerovi se nelíbilo, že straničtí předáci s velkou houževnatostí prosazovali kandidaturu Franze Guggenberga, syna Otto Guggenberga, který však ve výboru obce zasedal jen krátce. Podporu Stremitzerově kandidatuře na úřad starosty dali konzervativci a liberálové. Aby se zachoval smír mezi konzervativní a křestanskou sociální stranou, tak konzervativci v poslední chvíli předložili kompromisní návrh „Stremitzer starosta, Franz von Guggenberg místostarosta“. Ale Křestanská sociální strana nadále trvala na Guggenbergovi a kompromisní žádost zamítla. Následné hlasování Stremitzer vyhrál. ${ }^{11}$ Konflikty zmírní až Stremitzerovo náhlé úmrtí na srdeční infarkt v srpnu 1915. ${ }^{12}$

Vypuknutí války je momentem, jenž náhle přerušuje hospodářský a kulturní vzestup města. $V$ prvé řadě válka znamená konec turistického ruchu, což postihlo na něj navázané služby, navíc došlo $\mathrm{k}$ silnému omezení práv místní správy vídeňskou vládou a armádou. Protože Brixen nebyl daleko od frontové linie, město se stalo zázemím pro tisíce vojáků a centrem, kam byli odváženi ranění [Parschalk 1999: 105-106]. Na podzim 1918 se frontová linie zhroutila a Jižní fronta se rozpadla. Pár dní po dohodě o př́měří ve Ville Giusti ze 4. listopadu 1918 italské jednotky obsadily Jižní Tyrolsko a s ním i Brixen. S podpisem mírové smlouvy v Saint-Germain-en-Laye se Jižní Tyrolsko definitivně stalo součástí Itálie a pro město Brixen to znamenalo hluboký řez do jeho správy a dalšího vývoje, zvláště nejistá právní situace představovala velký problém [Sparber 1957: 130-132].

Aby se mohli lépe vyrovnat s narůstajícími problémy, spojili se v ř́jnu 1918 dř́ivější rivalové katoličtí konzervativci a křestanští socialisté a vytvořili katolickou Tyrolskou lidovou stranu (Tiroler Volkspartei) [Kriechbaumer 2006: 107]. Starostenský post byl v průběhu války uprázdněn a město ř́dili zástupci Franz Oberkofler, Roman Schwaighofer a Franz von Guggenberg, jenž byl na konci války v listopadu 1918 zvolen starostou. ${ }^{13}$ Volby do zastupitelstva se uskutečnily až v lednu 1922. A to podle italského volebního zákona, který byl v rozporu s původním rakouským, založeným na kumulačním hlasování dle daňové asignace. ${ }^{14}$ Nyní měl každý občan, bez ohledu na svůj majetek a vzdělání, rovné hlasovací právo. V Brixenu se sní̌il počet zastupitelů z 30 na 20 míst s tím, že nejsilnější strana mohla získat maximálně čtyři pětiny (16) křesel, zatímco pětina křesel zůstala jako minimum straně na druhém místě. Proto vzhledem k úplně nové politické situaci se strany zaměřily

11 Srov. Bozner Nachrichten, Die Bürgermeisterwahl in Brixen, 7. ř́ina 1913, s. 1; Meraner Zeitung, Der Kampf um Brixen, 7. listopadu 1913, s. 1; Brixener Chronik, 7. ř́ína 1913, s. 2; Brixener Chronik, 10. ř́ijna 1915, s. 4.

12 Brixener Chronik, 14. srpna 1915, s. 8.

13 Austrier Blätter, č. 26, 1957, s. 312-313.

14 Katholischen Sonntagsblätter 13, 1939, č. 7, s. 3. 
na společný postup. Tyrolská lidová strana do nově dvacetimístného zastupitelstva předložila 16 kandidátů a s druhou významnou německou stranou v Brixenu, liberály, se lidovci dohodli na obsazení zbývajících čtyř míst společné kandidátky. S touto sjednocující taktikou tyto (původně tři) strany doufaly, že získají všech 20 křesel a zamezí tím jak italským uskupením, tak sociálním demokratům vstup do obecní rady. Bohužel se obnovily staré konflikty mezi konzervativci a křestanskými socialisty [SLA Bozen b); Kasslatter 1988: 22-24] a jednotlivé frakce nebyly schopné dohody ohledně volby starosty. Tři kola tajného hlasování výsledek nepřinesla. Tak po období sedisvakance, kdy byl starostenský post neobsazen a agendu spravoval zástupce Josef Widmann, Brixen získal starostu Romana Schwaighofera až losováním [Milesi 2002: 14].15

Hospodářský kolaps politicky již italského Brixenu, který se záhy dostavil, je právě úzce spojen s přechodem města pod italskou správu. Byly silně poškozeny letité vazby, což se nejjasněji projevilo ekonomickou recesí v oblasti obchodu, lázeňství a turismu [srov. Leonardi 1998: 215-225]. Městská správa musela řešit zcela nové italské právní předpisy, vyrovnat se s obrovským dluhovým zatížením a důsledky nepř́íznivého směnného kurzu koruny a liry, nemluvě o prudké inflaci, která podkopala každou investiční př́ležitost [Steuerer 1980: 119-121]. Ekonomický úpadek Brixenu zatěžoval městské podniky a zavření Brennerského průsmyku, spojené s bolestivým dělením Tyrolska na dvě části, přerušilo tradiční obchodní vztahy se střední Evropou. Pro místní sedláky bylo obtížné vstoupit na nové trhy [Milesi 2002: 12].

V moderních dějinách města italský prvek původně nehrál žádnou roli, v roce 1910 se k italské národnosti v celém Jižním Tyrolsku hlásila necelá $3 \%$ obyvatel a nejinak tomu bylo v Brixenu [Boelitz 1930: 79; Rainer 2010: 205-207]. Vše se ovšem mění po začlenění do Italského království. Přílivem velkého množství Italů dochází k rychlé proměně národnostního složení obyvatel města. Jestliže se k italské obcovací řeči hlásilo ještě v roce 1918 jen asi 2,7 \%, tak za pouhé tři roky do roku 1921 stoupl jejich počet až na zhruba 26 \% z 5773 obyvatel [Gelmi 2000: 251-255]. Také celkový počet obyvatel v krátké době vzrostl z cca 5800 na 7000 osob [Mock 2004: 258]. Posílení italského elementu však nelze vnímat pouze jako následek nárůstu italojazyčných nově příchozích. Určitá část měštanů rovněž připojení k Italskému království vyhodnotila tak, že pro ně bude lepší, přihlásí-li se k novému státu i jazykově.

Inkorporace do Italského království tvrdě dolehla také na církev. S koncem rakouské monarchie dochází ke znejistění právního postavení církevních institucí, což mělo na Brixen jakožto bývalé biskupské město spravující rozsáhlou diecézi negativní dopad. Svatý stolec se kvưli nejasné politické situaci choval váhavě a v Brixenu zavládla mezi duchovenstvem nervozita ohledně připojení ke státu, jehož vztahy s církví od prolomení Porta Pia vykazovaly trvalé napětí. Financování bylo problematické a kvůli devalvaci rakouské koruny se duchovenstvo ocitlo v obtížné situaci. Kněží v diecézi se mohli rozhodnout, zda zůstat v rakouské části, nebo zda chtějí působit v té jižní. Ačkoli duchovenstvo změny neslo těžce, své náboženské povinnosti vědomě plnili v duchu evangelia, $v$ čemž jim (kromě zákazu veřejného uctívání některých svátků) nebyly kladeny překážky [Gelmi 1998: 2-4].

15 BrixnerBote, Festabend zu Ehren des neuen Bürgermeisters, 22. března 1922, s. 1. 
Ne všichni se však s novou situací dokázali vyrovnat. Z církevních kruhů nejviditelnější a nejvlivnější osobností byl pomocný biskup Bolzansko-brixenské diecéze a po odchodu do Rakouska arcibiskup salcburský Sigismund Waitz ${ }^{16}$, syn podnikatele Karla Waitze a Julie Gasserové, neteře biskupa Vinzenze Gassera. Waitz se stal velkým apologetem myšlenek papeže Pia XI. a byl pevně svázán s posledním rakouským císařem Karlem, jehož byl ve Vídni vychovatelem a učitelem náboženství. Po válce se snažil vyjednat vznik samostatného Tyrolska. Jako velmi silně prorakousky orientovaný se těžce smiřoval s přechodem Brixenu do italských rukou. Po odchodu do rakouské části Tyrolska byl v polovině 30. let zvolen salcburským arcibiskupem a je považován za jednoho z nejvýznamnějších představitelů církve první rakouské republiky. ${ }^{17}$

Když už se brixenské městské elity a duchovenstvo mohly domnívat, že největší změny již mají za sebou a stabilizace bude pokračovat, 28. ř́ijen 1922 nastavení zcela změnil. Po tzv. pochodu na Rím ${ }^{18}$ se $\mathrm{k}$ moci dostává Benito Mussolini, dochází k demontáži demokratických struktur a postupné konsolidaci fašistického režimu. V souladu s Mussoliniho představami ohledně proměny společnosti a zejména ve vztahu k neitalskému obyvatelstvu je v celé jihotyrolské oblasti zahájena systematická násilná italianizace. ${ }^{19} \mathrm{~V}$ důsledku toho byly zaznamenány další ekonomické ztráty a opětovný propad cestovního ruchu. Pro Brixen začaly těžké časy.

Dne 11. ledna 1923 vstoupil v platnost nový obecní zákon, který značným zpo̊sobem omezil pravomoci municipalit. S rozšířením italské komunální legislativy na Jižní Tyrolsko se obce dostaly pod zvýšenou kontrolu státu, kdy každé rozhodnutí muselo být předloženo prefektovi. Protože si starosta Roman Schwaighofer dovolil hovořit o Brixenu jako o „městě na okupovaném území, byl do měsíce z úřadu suspendován a v říjnu 1923 byla místní rada rozpuštěna. Pravomoci převzal (nikoliv však na dlouho) komisař prefektury Luciano Urli [Parschalk 1999: 111-126; Milesi 2002: 14]. Rozpuštění politických samosprávních orgánů napomohly rovněž dlouhá léta doutnající spory v rámci místní rady. Občané marně doufali, že nová právní ustanovení, nadiktovaná v Římě, ukončí trvající rozepře mezi obecními zastupiteli. Konflikty mezi stranami a až osobní nepřátelství však pokračovaly, a to i na úkor městského života. Jen po krátkém intermezzu zvolené reprezentace vymezeném volbami v srpnu 1924, kdy se starostou stal dr. Walther Lutz, je po zásahu prefekta Guadagniniho v polovině roku 1925 obecní rada opět rozpuštěna, tentokrát na dlouhých 27 let [Milesi 2002: 14-15].

Administrativní chaos a napětí násobí konflikty s fašistickými orgány. Německy hovořící úředníci, do značné míry zavaleni a ochromeni novou, v italštině vydávanou legislativou, se dostávali do střetů s fašistickými úřady a reprezentanty a mnozí z nich jsou během krátké doby propuštěni ze služby. Královský výnos ze 4. února 1926 staví namísto zvole-

16 K Waitzovi souhrnně [Alexander 2010, zde zejména Kogler 2010: 293-330; Jablonka 1971].

17 V r. 1938 Waitz odsoudil anšlus Rakouska a jako jeden z mála biskupů hlasitě odmítal nacistické útoky na církev. Po krátkém domácím vězení a odchodu z arcibiskupství dožil v ústraní. V politických otázkách Sigismund Waitz upozorňoval na vítězství chamtivosti, ve společenské sféře se věnoval otázkám vzdělávání, lidské bídy a vysoké nezaměstnanosti [Dokumentationsarchiv des österreichischen Wiederstandes: 168; Gaydosh 2017: 112].

18 K útoku fašistických squadre pod vedením Achille Staraceho a Itala Balba na Trento a Bolzano (tzv. pochod na Bolzano) došlo již v na začátku ř́ina 1922 [Bosworth 2006: 179].

19 K nástupu fašistů v Jižním Tyrolsku viz [Lechner 2011: 50-65]. 
ného starosty do čela obce podestà s významnými pravomocemi, jenž je podř́ízen kontrole prefekta [Segatori 2003: 11] a pro Brixen jmenován v roce 1927. ${ }^{20}$ Ưrednické kanceláre, často jen na krátký čas, obsadili komisaři prefektury, kteří byli občany pro svou neschopnost považováni za podvodníky a ignoranty. ${ }^{21}$ Lze říci, že $\mathrm{v}$ této době občané rezignovali. Pro Brixen (ted’ již Bressanone) fašismus s jeho „fasádním“ korporátním systémem a autoritářskými omezeními znamenal na dlouhé období úpadek ve všech sférách občanské společnosti [Gelmi 2000: 254].

Ani I. světová válka, ani přechod Brixenu pod italskou správu nedokázal narušit dlouholeté vazby mezi místními elitami z řad významných rodin (Guggenbergové, Schwaighoferové aj.), které i přes překotné změny zastupovaly zájmy měštanských vrstev. Stejně jako jeho otec a strýc byl Franz Guggenberg členem křestansko-sociální strany. Spolu s otcem založili Brixenskou-bolzanskou Vereinsbank (později Tiroler Vereinsbank), jíž jako ředitel a předseda představenstva vedl [Parschalk 1999: 109; Assecuranz-Compass: 179]. Poté, co byl za války na srbské frontě zajat a později propuštěn, vrátil se v létě roku 1917 do Brixenu. Zde jej zastupitelé zvolili starostou. Jako politik vyzýval obyvatele ke klidu a opatrnosti vůči italským okupantům. V roce 1919 se oženil s dcerou bývalého císařského velitele Wilhelma Jaksche. Už v ř́ijnu 1920 však rezignoval na starostenský post a vrátil se do vedení banky v Bolzanu. Za fašistické diktatury mu byla zakázána politická činnost, takže se věnoval správě rozsáhlého rodinného majetku. ${ }^{22}$ Vliv Guggenbergů v křestanské sociální straně ještě více akcentuje Franzův strýc Atanas, který po skvělé kariéře v rakousko-uherské armádě, kde to dotáhl až na brigádního generála, se po svém odchodu do penze v r. 1897 zapojil do lokální i národní politiky a spolkové činnosti (předsedal rybářskému spolku, byl členem ústředního výboru asociace cestovního ruchu v Tyrolsku aj.). V r. 1907 byl schopný zvítězit ve volbách do řišské rady už v prvním kole hlasování. O čtyři roky později těsně obhájil svůj mandát proti kandidátovi liberálů Josefu Rohracherovi [Freund 1911: 184; ÖBL 1959: 105].

Sílu vlivu tradičních honoračních rodin na brixenskou politiku podtrhují hostinský a hoteliér Johann Stremitzer, spř́zněný s dalšími důležitými brixenskými rodinami Kehlů a Pohlů [srov. Haid 2004], a Ignaz Mallepell, majitel brixenského mlýna. Stremitzer umně využíval své známosti jakožto velkého místního hoteliéra, v prostorách jehož hotelu se scházely místní spolky a zájmová sdružení. Tímto byl jeho hotel „U zeleného stromu“ vyhlášený. ${ }^{23}$ Jeho dvě sestry Johanna a Franziska byly zpěvačkami světoznámého folklorního tyrolského souboru Jakoba Schöpfera [Fischnaler 1929: 132; Herrmann-Schneider 1995:

20 Je třeba dodat, že přes podřízení fašistické strany státu pokračovaly kompetenční spory, které pramenily z konkurence mezi prefekty jakožto představiteli (fašistického) státu na straně jedné a reprezentanty fašistické strany (lokálními fašistickými rasy [pl. i ras]) na straně druhé. Mnozí prefekti byli postupně nahrazováni exponenty fašistické strany. Podrobněji [Gentile 2005: 181].

${ }^{21}$ Svou leností a okázalým vystupováním byl známý obecní tajemník dr. Fea, který se nepokrytě snažil zajištovat pozice pro známé z rodné Cremony, jakožto „staré“ a fašismu oddané provincie. Mezi lidmi se následně Brixenu začalo přezdívat Nová Cremona [Milesi 2002: 16].

22 Po válce a založení Jihotyrolské lidové strany (Südtiroler Volkspartei, SVP), regionální autonomistické formace a úspěšné představitelky německojazyčných a rétorománských obyvatel, v roce 1945 se Franz stal členem výboru a předsedou okresu Bressanone. Jeho bratr Otto se na začátku 50. let dokonce stává předsedou SVP. Austrier Blätter č. 26, 1957, s. 312-313. Otto von Guggenberg byl v letech 1948-1958 rovněž poslancem italského parlamentu [Parlamento italiano]. K poválečnému vývoji SVP viz [Strmiska 1998: 111-118].

23 Např. Brixener Chronik, 29. května 1913, s. 3; Brixener Chronik, Der Bürgemeister von Brixen Johann Stremitzer gestorben, 10. srpna 1915, s. 6. 
108]. Rodina Mallepelů pak byla úzce spjata s regionálně významným mlýnem v Brixenu. Mlynář v třetí generaci Ignaz Mallepell hrál důležitou roli ve společenském životě města. Kdekoli se objevil, brzy se kolem něj vytvořil kruh prrátel a známých. Jako dlouholetý člen městské rady, velitel hasičského sboru v Brixenu a předseda okresního hasičského sboru si získal známost a velké renomé po celé oblasti, které si udržoval prostřednictvím obchodních vztahů a rozvoje mlýna. Během I. světové války získal velké zásluhy díky službám pro zajištění obyvatelstva. Jeho pověst velkorysého a nesobeckého člověka mu společensky nesmírně pomáhala a zajištovala stálý vliv na chod samosprávy [SLA Bozen a)].

Zajímavou a progresivní osobnost můžeme vidět v synovi barvířského mistra Franze Schwaighofera Romanovi. Roman Schwaighofer napodobil svého otce, dlouholetého radního, a politicky se angažoval, přičemž podporoval progresivní změny. Po otci také převzal živnost a v době války se v radě věnuje agendě, která příslušela starostovi města, jehož post byl v letech 1915-1917 uprázdněný. V neutěšené době fašistického vzestupu byl zvolen starostou, aby byl o rok později po kritice nového režimu na základě nového zákona $\mathrm{z}$ úřadu odvolán [Heiss 1999: 416; Königsrainer 1995: 118-119].

V Brixenu a jeho okolí rovněž žily významné osobnosti kulturního života - umělci, sběratelé, spisovatelé a historici. At’ už jím byl orientalista Jakob Philipp Fallmerayer, nebo folklorista a sběratel Adolf Heyl, který po přistěhování do Brixenu pracoval jako spisovatel, ${ }^{24}$ dále historici Theodor Mairhofer a Hartmann Ammann, jenž získal největší zásluhy v oblasti archivnictví a řídil arcibiskupský soudní archiv [Gelmi 2000: 245]. Vyhlášené lázeňské město přitahovalo pozoruhodné osobnosti, jež se rychle začlenily mezi místní elity. Mezi nimi vynikal rodák $\mathrm{z}$ dobře situované richmondské rodiny ve státě Indiana, římský katolík, spisovatel, znalec historie ${ }^{25}$ a především diplomat Francis Augustus MacNutt. V roce 1882 odjel na studia do Evropy, následně udělal velkou kariéru v diplomacii, kdy působil ve Španělsku, Osmanském Turecku nebo Káhiře a s manželkou Margaret se usadil v Rímě. MacNutt měl velký vliv ve vatikánských kruzích a byl blízkým přítelem hned tří papežů - Lva XIII., Pia X. a Benedikta XV. Na rakouském císařském dvoře navázal úzké vazby s císařskou rodinou včetně císařovny Zity. MacNutt si oblíbil lázeňský Brixen a jako letní dům koupil v roce 1903 zámeček Ratzötz ${ }^{26}$, jenž se poté, co opustil Rím, stal centrem brixenského společenského života. Aktivně se zapojil nejen do spolkových záležitostí, ale také do stavebních a urbanizačních akcí, oficiálně byl rovněž prvním majitelem automobilu ve městě. Za války, po vyhlášení války Rakousku Spojenými státy, se jej pokoušeli Rakušané zatknout, ale po zásahu samosprávy a brixenského biskupa Franze Eggera od toho ustoupili. Před svou smrtí (zemřel v r. 1927) MacNutt daroval velkou část svého bohatství městu na společenské a kulturní účely [Mock 2017: 32-36]. ${ }^{27}$

24 Dolomiten - Tagblatt der Südtiroler, Elmar Oberkofler, Tirols grösster Sagensammler, 21. května 1997.

25 Mezi jeho hlavní a citovaná díla patří: MacNutt, Francis Augustus [1909]. Fernando Cortes and the Conquest of Mexico, 1485-1547. New York - London: G. P. Putnam's Sons, The Knickerbocker Press. Francis Augustus MacNutt, Francis, Augustus [1908]. Fernando Cortes: His Five Letters of Relation to the Emperor Charles V, 1519-1526. New York - London: G. P. Putnam's Sons, The Knickerbocker Press.

26 Volksbote, 16. února 1928, s. 9.

27 Viz rovněž MacNuttovy vzpomínky [MacNutt 2017]. 


\section{Uherské Hradiště}

Agrární střed jihovýchodní Moravy město Uherské Hradiště bylo správním centrem regionu. Už od vzniku samospráv po polovině 19. století se zde střetávaly rozdílné zájmy tradiční honorace, řemeslníků, živnostníků a vzdělanostních vrstev. V obecním zastupitelstvu dominovali bohatí majitelé nemovitostí (klassischen Grossbesitzer) ${ }^{28}$, kteří občanům a úředníkům samospráv dodávali jistotu a rozptylovali tak jejich obavy o další vývoj. V prvních desetiletích 20. století českou společností prostupující sociální diferenciace pomohla vstupu mezi lokální elity zejména advokátům, kteří svým působením mj. profesionalizovali a formalizovali jednání obecních zastupitelstev. Jejich vliv byl rostoucí a dlouhodobý [srov. Fasora 2005: 354-356]. ${ }^{29}$ V přelomových 90. letech 19. století docházelo nejprve k pozvolným a pak zrychleným změnám. Velká část elit se dokázala dostatečně rychle etablovat a přizpůsobit novým výzvám [srov. Fröschl 2000: 388-390]. Tradiční měštanské elity a nová, rychle bohatnoucí skupina měštanů (obchodníci, podnikatelé, lékaři, advokáti) existují delší dobu vedle sebe, ale nedochází k sociální a politické integraci obou skupin. V zastupitelstvech a v radách si až do 1. světové války udržely vliv spř́izněné staré měštanské rodiny Pražáků, Pogliesů, Aulichů a Prillingerů. I po přechodu do nového státního zřízení zůstává Uherské Hradiště statutárním městem. Ovšem přijaté změny ${ }^{30}$ omezily či zrušily instituce typu měštanského práva, které napomáhalo tomu, že pouze měštané mohli získávat výhody plynoucí z městských fondů a nadací, přičemž takové nastavení vyhovovalo v prvé řadě německé menšině, jež si tím mimo jiné zajištovala většinu v prvním volebním sboru.

V nábožensky silně založeném hradišţském kraji byl politický vliv katolíků v uherskohradištském zastupitelstvu překvapivě zcela zanedbatelný; nedokázali čelit nastupujícím národním a levicovým stranám. Spory konzervativně křestanských sil s lidovou pokrokovou stranou ${ }^{31}$ pokračovaly po celé první a druhé desetiletí 20 . století a vedly až ke stavu, kdy o regulérnosti voleb musely rozhodovat soudy [SOkA UHf)]. Vzestupem pokrokových stran $^{32}$ začíná ústup dominance tradičních uherskohradištských rodin v lokální politice $[S O k A U H l)]^{33}$, přičemž v politice ostř́lení a vždy lavírující německo-židovští obchodníci a řemeslníci se přiklonili k novému establishmentu [SOkA UH e)]. ${ }^{34}$

28 Vliv a sociální status na maloměstě si udrželi velcí vlastníci nemovitostí. Srov. [Čoupek 2000: 377; Bruckmüller 1999: 14].

29 V Uherském Hradišti dosáhli dva starostenské funkce; JUDr. Jan Konečný byl zvolen starostou v r. 1903 a JUDr. Václav Pitra se stal zastupujícím starostou v letech 1905-1906.

30 Novela obecního zřízení č. 76 Sb. ze 7. 2. 1919 a nový volební řád č. 75 Sb. z 31. 1. 1919.

31 Moravská lidová strana, vedená advokátem Františkem Vysloužilem, měla v 90. letech 19. stol. společnou kandidátní listinu s měštanskou národní stranou. Kompromisní stav se po r. 1900 mění v ostré spory, zejména v otázkách hospodaření města a počeštění městské správy. Lidová strana začala být podporována stoupenci pokrokových hnutí (následně vzniká lidově pokroková strana). Srov. [SOkA UH i)].

32 V únoru 1918 se slučují mladočeši se Stranou státoprávně pokrokovou, Moravskou lidově-pokrokovou stranou a částí Pokrokové strany (realisté) v novou stranu Česká státoprávní demokracie. V r. 1919 mění název na Československou národní demokracii. K pokrokářům např. [Malír 2014: 415-450; Malír - Marek a kol. 2005; Tomeš 2013].

33 Společensky velmi aktivní a vlivný stavitel Josef Schaniak svou velkou stavební firmu prodal, Robert Aulich ml., syn velkoobchodníka a bývalého starosty Roberta Aulicha, v roce 1915 ukončil obchodní živnost.

34 Např. Julius Hugo Berger, Hermann Braun, Abraham Klein, Gottfried Karl Hönig, Heřman Morgenstern, Karel Schindler, Ferdinand Seyfert, aj., viz též [Zapletal - Zapletalová 2019: 373]. 
Lidoví pokrokáři (resp. později národní demokraté) získali na dlouhá desetiletí na radnici většinu a jejich představitel inženýr František Beneš setrval v čele samosprávy i po vzniku Československé republiky. Na podzim roku 1918 Beneš a jeho političtí spojenci velmi rychle pochopili, jak velkou změnou se stane přechod ze stále víceméně monarchistického uspořádání Rakouska-Uherska v nový republikánský systém Československého státu. Ř́dili drobné pronárodní akce, které vyvrcholily v ranních hodinách 29. ř́ijna, kdy byly spontánně odstraňovány rakouské symboly [SOkA UHg): 191]. Nedobrá hospodářská situace, ještě umocněná nutností zásobovat vojsko (tzv. Slováckou brigádu) bojující na Slovensku proti mad’arským jednotkám, se projevila v nedostatku základních potravin, zvyšování cen a projevech lichvy. Hněv nespokojených zejména $\mathrm{z}$ nižších vrstev se obrátil proti nejbohatším obchodníkům a živnostníkům z řad německých židů. Nespokojenci v listopadu doslova rozkradli sklady továrníka Emanuela Fürsta a pouze vojenský zásah zabránil dalšímu plenění [SOkA UH c)]. Situace se ve městě uklidňovala jen velmi pozvolna.

V prvních volbách do obecního zastupitelstva v červnu 1919 vítězí blok občanských stran: národní demokracie, v čele s oblíbeným starostou Františkem Benešem a dr. Josefem Seifertem, živnostensko-obchodní a republikánské (agrární) se ziskem 21 mandátů z 36 [SOkA UH i)]. Sice se od národních demokratů ještě před volbami oddělila skupina kolem gymnaziálního profesora, archiváře a topografa Bohumila Fišera [Makariusová 2014: 243], která obnovila pokrokovou stranu a hájila zájmy vzdělanostních vrstev, ale její volební výsledek nebyl takový, aby mohla obsadit posty radních. Po třech mandátech získaly strany lidová, lidová židovská, pokroková a sociálně demokratická [SOkA UH k)]. Za spojením občanských stran s odlišným programem do jednoho politického bloku můžeme vidět ryzí pragmatismus jeho tvưrců. Společným cílem bylo udržet si voliče z vyšších majetkových vrstev, být hrází proti radikální levici stejně jako konzervativnímu katolicismu a zároveň zachovat maloměstsko-obchodnicko-úřednický charakter města. Poválečná situace byla značně turbulentní a ve znamení silných revolučních nálad, které vrcholí generální stávkou v prosinci 1920. Občanský blok byl však schopen tento dramatický vývoj překonat, a to i přes vznik místní buňky komunistické strany v květnu $1921 .{ }^{35}$

Pokud považujeme růst populace za důležitý ukazatel prosperity a změny, tak Uherské Hradiště se představuje mezi lety 1910 a 1925 jako ospalé maloměsto na 249 ha s nijak velkým růstem počtu obyvatel a národnostně indiferentní a zmenšující se německou menšinou. ${ }^{36}$ Význam města $\mathrm{v}$ prvních letech republiky byl zvýrazněn tím, že bylo stále sídlem volebního kraje, krajského soudu a řady okresních úřadů a institucí. Zástupci Československé strany lidové, která vznikla spojením katolických stran, byl poprvé vysloven požadavek na vytvoření velkého souměstí spojením města s okolními obcemi. Začala nová éra plná velkých sociálních rozporů, hospodářských krizí, ale i růstu města a zásadních urbanistických úprav směřovaných obecně k modernizaci a zlepšení celkového vzhledu. První elektrické osvětlení bylo zavedeno již před válkou a k dokončení elektrifikace města

35 Ve dnech 13.-14. prosince 1920 se radikální levicový (prekomunistický) blok, vedený Janem Macenaurem z Uherského Hradiště a Čeňkem Zichem z Mařatic, pokusil převzít moc. Státní správa rychle zasáhla a „puč“ svými opatřeními eliminovala. Srov. [Čerešňák 1971: 11-14].

36 V r. 1910 počet obyvatel činil 5174 osob, v r. 1921 to bylo 5682 . Pokles počtu těch, kteří se hlásili k německé národnosti (v r. 1910 - 369, 1921 - 157 osob, viz tabulka č. 1 výše), jen pokračoval v trendu posledních 30 let, kdy německá menšina de facto ztratila vliv na chod města. Ve sledovaných letech je tento pokles spojen zejména s německou židovskou skupinou obchodníků a řemeslníků, kteří pod vlivem politických změn změnili svou národnostní př́slušnost. 
[SOkA UH j)] došlo do deseti let (1922) napojením na Západomoravské elektrárny, následovalo vybudování zemské nemocnice (1923). Městské elity si byly velmi dobře vědomy toho, jak velký ekonomický potenciál se skrývá v politickém ovládnutí peněžních ústavů (Městské spořitelny, Rolnické záložny aj.), odkud mohly nezbytné finance získávat [Čoupek 2000: 363-364].

Vedle radikální levice, která o sobě dávala velmi hlasitě vědět, zde již od vzniku republiky vystupovala „klidná síla“ zosobněná katolickým knězem a farářem Ignácem Zanáškou. Zanáška byl typickým představitelem umírněných katolických náboženských kruhů, odmítajících vytváření organizovaných aktivistických skupin. Přestál poválečný protikatolický radikalismus českých gymnaziálních studentů a profesorů, kteří spojovali katolickou církev s padlou habsburskou monarchií. Bylo do značné míry jeho zásluhou, že v Hradišti nedošlo $\mathrm{k}$ větším náboženským konfliktům a město si celkově, i přes působení českobratrské církve evangelické, zachovalo (alespoň navenek) výrazně katolický duchovní ráz. Zanáška se společensky až nezvykle velmi silně angažoval. Jako amatérský historik sbíral a publikoval statě k dějinám farnosti. Ale pro měštany se stal nejvíce viditelným ve chvíli, kdy stanul v čele druhé největší slovácké finanční instituce - Rolnické záložny [SOkA $U H$ h); Tethal 2004: 219]. Rolníkům poskytovala překlenovací a investiční úvěry od roku 1871 a již na konci 90 . let disponovala vklady přes 610000 zlatých a měla na 1100 členů [Jarušek 1934: 80]. Zprvu ji ř́dil advokát a poslanec rríšského sněmu František Šrom a později Antonín Cetkovský, uherskohradištský farář a Zanáškův předchůdce [Galusek 1879: 64-65, 110]. Na přelomu 19. a 20. století byla záložna silnou institucí a Zanáška si jejím vedením zajistil patřičný respekt nejen u slováckých rolníkủ, ale také u předních představitelů samosprávy.

Koho můžeme považovat za nositele poválečných změn a zároveň patř́ k lokálním elitám? Lze konstatovat, že tehdejší společenský vzestup by byl nemyslitelný bez napojení na staré, původní elity, nebơ spojení s nimi poskytovalo mimo jiné cenný symbolický kapitál. Tento způsob vzestupu je možné sledovat především na proměně specifické vzdělanostní skupiny - advokátech. Uherské Hradiště mělo kromě sídla řady státních úřadů pro právnickou obec zásadní význam zejména díky prŕtomnosti krajského soudu a uherskohradištští advokáti patřili k elitě místní společnosti. To lze ilustrovat i na typu jejich bydlení, kdy většina $\mathrm{z}$ nich žila $\mathrm{v}$ bytech nadstandardní velikosti. ${ }^{37}$ Svými př́ijmy, celkovým majetkem a počtem služebnictva se řadili mezi nejbohatší občany, zároveň disponovali vlivem na politické, spolkové a kulturní dění. V Uherském Hradišti působilo hned několik advokátů, kteří se stali významnými př̌edstaviteli české politiky. Mezi nimi vynikal Josef Seifert, který patřil k pokrokářum, za něž byl dvakrát zvolen do Moravského zemského sněmu, a po vzniku republiky se stal poslancem Národního shromáždění a senátorem. Byl také úporným obhájcem českého školství ve Vídni před říšským soudem. ${ }^{38}$ Po roce 1918 se lidová strana pokroková, v níž se před válkou Josef Seifert angažoval, spojila s dalšími stranami ve Státoprávní demokratickou stranu, posléze přejmenovanou na Národní demokratickou stranu. Seifert byl dlouholetým členem správního výboru městské spořitelny, předsedou

37 Např. advokát Josef Seifert, o němž níže, obýval s rodinou desetipokojový byt. Velmi zajímavý je také přesun bydliště advokátů ze středu města a jejich koncentrace do prostoru kolem nové budovy krajského soudu na dnešním Palackého náměstí. Srov. [Rája 2015: 175-179].

38 Ve volbách do zemského sněmu v roce 1906 porazil staročeského kandidáta a bývalého starostu města Josefa Stancla st. [Navrátil 1930: 391; Malír 1978-1979: 107]. 
finanční komise a členem městského výboru v letech 1912-1919. Seifert patřil k vyhledávaným advokátům v oblasti trestního práva, za což si nechával dobře zaplatit, a byl proto radikální levicí nenáviděn a dehonestován. Po jeho smrti (1926) převzal advokátní kancelář zet', uherskobrodský advokát a starosta (1919-1928), Jan Renner [Malír 2012: 588-589].

V Hradišti i po vzniku republiky nacházíme zástupce tradičních vrstev a vzdělané střední tř́idy. Obě skupiny, které nemůžeme od sebe oddělit, lze charakterizovat sdílenými hodnotami, jako je pozitivní postoj ke vzdělávání, zavržení náboženského interpretačního monopolu a odmítání relativizace církevního vlivu na politický a soukromý život. Tento na maloměstě tak častý názor byl směrodatný v mnoha spolcích. Jako politická platforma sloužil především „blok občanských stran“. Tyto elity reprezentoval v prvé řadě sám starosta František Beneš ${ }^{39}$. Beneš byl představitelem lidové pokrokové strany a zakladatel místní organizace České státoprávní demokracie (duben 1918), pozdější Československé národní strany demokratické. Za války patřil k aktivním činitelům domácího protihabsburského odboje Mafie. V jeho vinném sklípku v Mařaticích bylo slavnostně oznámeno vyhlášení samostatné Československé republiky [SOkA UH g): 191]. Jeho profesní a později i soukromý život je úzce spjat s Uherským Hradištěm, kde ještě před svým vstupem do politiky spolu s architektem Dominikem Feyem v roce 1898 společně provozovali architektonickou kancelár. Pracovně velmi vytížený Fey také později zaujímal post městského architekta [Bergmann 2007: 33-39]. Obratným jednáním s úřady se Benešovi hned po válce podařilo zajistit vznik obchodní akademie, tolik potřebné instituce pro vzdělávání velkého množství dětí ze živnostenských a obchodnických rodin. Společensky nesmírně činný Beneš stál rovněž za vznikem Národopisné a muzejní společnosti spolu se správcem muzejních sbírek Františkem Kretzem. Kretz, člověk velmi pracovitý, ovšem i náladový a neústupný, si s Benešem nesedl po stránce pracovní ani lidské, oba se zcela míjeli nejen politicky, ale i osobnostními rysy. Nejenže se nepodařilo zajistit financování pro plánovanou novou budovu Slováckého muzea, ale po Kretzově smrti je většina jeho osobní sbírky rozprodána soukromým sběratelům [Jančář 1965: 17-19]. V lednu 1931 šestašedesátiletý František Beneš po dlouhé nemoci rezignoval na post starosty a byl nahrazen svým spolustraníkem a dlouholetým soudním radou Metodějem Garlíkem.

Zájmy obchodníků zastupoval obchodník s šicími stroji, dlouholetý člen výboru a náměstek starostů Beneše a Garlíka Antonín Keller ml. Kombinace několika faktorů vedla k vytvoření relativně silné skupiny obchodníků a živnostníků. Spojovaly je vzdělání, pracovitost, podnikavost a ochota věnovat se politice, včetně přijetí funkcí ve sdruženích a veřejných úřadech, ale i „inteligentni“ sňatková politika. V prvních dvou desetiletích 20. století se do popředí dostávají reprezentanti vzdělanostních vrstev. Jejími zástupci byli především soudní vězeňský lékař Vincenc Hejník a středoškolský profesor Bohumil Fišer. Fišer pocházející z Mladé Boleslavi a vyrůstající v katolické rodině v mládí nepatřil $\mathrm{k}$ nejlepším studentům, jak dokazují např. dostatečné z latiny a řečtiny [SOkA UH b)], ovšem po nástupu na gymnázium v Uherském Hradišti jeho profesní dráha stoupala výše a výše. Už v mládí se stal členem České strany pokrokové a po jejím zániku vstupuje do Československé strany národně socialistické, za kterou dvakrát kandiduje do Poslanecké sněmovny. Činorodý Fišer působil nejen jako městský archivář, ale zejména jako žurnalista. Vedl týdeník „Palacký“ a byl neúnavným přispěvatelem a ideovým vůdcem periodika

39 K jeho osobě např. [Čoupek 1997: 14]. 
„Naše Slovácko“. Pro město Uherské Hradiště sepsal dvě publikace: „Paměti hradištské“ a „Topografie města Uherského Hradiště“, dílo, jež dosáhlo ocenění historické obce [SOkA $U H a) .^{40}$

Jako jinde i v Hradišti staré vazby pomohly otevř́t nejedny dveře a navázat nové obchodní kontakty. Tato vzájemná propojení lze sledovat na mnoha př́padech. Např́iklad radní Julius Kopp byl v mládí asistentem u proslulé lokální stavební firmy Josefa Schaniaka. Firmu posléze od Schaniaka koupil a se stavitelem Františkem Brožem nejen stavěli, ale také provozovali velkoobchod se stavebninami a politicky hájili zájmy voličů lidové pokrokové strany. Další, kloboučník Jan Slunečko-Sohar, adoptivní syn Matyáše Slunečka, jednoho $\mathrm{z}$ vůdčích představitelů tradiční měštanské (purkmistrovské) strany, viditelně nesdílel otcovy názory a za I. republiky zastupoval pokrokáře. Př́klad vzájemného propojení tradičních měštanských rodin vidíme $\mathrm{v}$ prípadě rodiny radního Rudolfa Römera, syna Ignáce Römera, obchodníka se dřevem a dlouholetého člena městského výboru (1886-1906), radního (1900-1906) a blízkého spolupracovníka starosty Jan Protzkara, zastupujícího tradiční honorační purkmistrovskou stranu. Rudolfova sestra Marie se provdala za správce velkostatku Zdeňka Stancla, syna prvního českého starosty Josefa Stancla st., hlavního představitele ústavověrné, později staročeské strany v Uherském Hradišti, která politicky soupeřila především s pokrokáři. Německo-židovské obchodníky v meziválečném období zastupoval dlouholetý radní Karel Schindler, syn Adolfa Schindlera, majitele obchodu se železem a koloniálním zbožím, který šel v otcových šlépějích nejen profesně, ale též politicky, s tragickým osobním koncem v Terezíně za nacistické okupace [Omelková 2009: 12; Pěkný 2001: 525-526; Hobzová 1991: 4].

\section{Závěr}

Ve vývoji obou původně agrárních maloměst z odlišných částí habsburské monarchie, jež byla vystavena zásadní politické změně státoprávního uspořádání, sledujeme významné rozdíly. Proměny vyžádané „,velkou politikou“ obě města výrazně zasáhnou, dopady redefinice národnostně-politického kontextu se však liší. Z pohledu života na subnárodní, lokální úrovni můžeme s nadsázkou říci, že Uherské Hradiště bylo městem „vítězným“, naopak Brixen pak městem „poraženým“.

Zatímco hradištský politický, hospodářský a kulturní vývoj byl spjat s vytouženým vznikem samostatného Československého státu, vývoj Brixenu, či lépe na dlouhou dobu již jen Bressanone, nabral z pohledu obyvatelstva opačný směr. Celá několik staletí rakouská oblast byla začleněna do entity kulturně a politicky odlišného státu a následně vystavena nástupu fašistického režimu tvrdě potlačujícího etnicko-jazykovou odlišnost jejích obyvatel. Po okupaci tyrolské oblasti italskými vojáky musely brixenské místní elity čelit do té doby nepředstavitelným a neznámým problémům. Kromě politické nejistoty jsou to zejména ekonomické těžkosti, které postihnou dosud úspěšně se rozvíjející a modernizující město, jež bylo díky značnému úsilí představitelů obce známé jako prestižní lázeňská destinace. Z kontextuálních proměn to byly prožité útrapy války a tlak vyplývající ze začlenění do jiného státního celku, záhy proměněného ve fašistické lo stato totalitario, jež pro brixenské maloměstské elity představovaly tu zásadní zkoušku. Je proto zajímavé sledovat,

40 Naše Slovácko, Nekrolog Bohumila Fišera, 6. září 1928. 
že postavení tradičních rodin ve sledovaném období se v ekonomicko-politickém systému maloměsta změnilo jen relativně málo. Lokálním elitám je zejména následkem problémů a restrikcí uvalených nástupem fašismu, který zarazil rovněž nastupující demokratizaci $\mathrm{v}$ podobě rozšiřeného volebního práva, odepřen přímý politický vliv v rámci volených orgánů, jejich společensko-ekonomické postavení a neformální vliv na dění ve městě však nadále přetrvávají. Jejich ukotvenost v rámci společnosti není existenciálně ohrožena ani nově příchozími, $\mathrm{v}$ př́ípadě Brixenu reprezentovanými zejména přibyvším italojazyčným obyvatelstvem či významnými osobnostmi, které si Brixen zvolily za svůj nový domov, z jejichž řad by mohlo dojít k rekrutování nových politických maloměstských elit. V případě Italů však kromě vnucené fašistické správy k rozhodujícímu průniku nedochází, vzdělaní jednotlivci z kategorie nových obyvatel pozice tradičních maloměstských elit rovněž nenaruší a působí zejména v kulturně-společenské oblasti.

Jistou konzervativnost hradištských voličů můžeme sledovat na tom, že ani po vzniku republiky ve městě nedochází k „zavrženi““ starých elit. Ty si stále udržovaly ekonomické i politické pozice a vzájemnou blízkost. Ne že by neexistovaly také četné př́íležitosti pro sociální interakci, ale tradiční vrstva zůstala během sledovaného období relativně stabilní, a to i když ztrácela politické pozice (už před válkou ztrácí Josef Stancl st. v Hradišti starostenský post). Dále se podobala tradičním klientským skupinám a udržovala si ekonomický status a společenskou prestiž mezi občany. To bylo možné jak spoluprací s elitami nově nastoupivšími či příchozími, tak zejména provázáním s nimi prostřednictvím úzkých rodinných svazků. Hospodářské záležitosti a společenské funkce ve svých rukou nadále drželi oni a jejich rodiny. Ale zase by však bylo př́liš snadné předpokládat kontinuitu tradičních městských struktur. Na jedné straně existence nových (vzdělanostních) elit dokazuje, že probíhaly moderní transformační procesy i po I. světové válce, v Hradišti spojené s osobou Františka Beneše. Na druhé straně však tyto skupiny umožňovaly pouze omezené, jemné přizpůsobení přechodu „starého“ na „moderni“ maloměstskou společnost. Po válce se ještě více projevila ideová propast mezi politickými tábory. Nejen že došlo $\mathrm{k}$ politické fragmentaci společnosti, ale už nebyly možné vazby mezi představiteli různých politických názorů, jako tomu bylo na konci 19. století např́iklad mezi dlouholetým starostou Janem Protzkarem, držícím zájmy tradiční honoračních rodin, a lékárníkem Josefem Stanclem, prvním „českým“ starostou Uherského Hradiště.

Lze konstatovat, že přes sledované posuny způsobené následky pokračujících modernizačních tendencí, $\mathrm{v}$ daném období spojených zejména s demokratizací prostřednictvím rozšiřování volebního práva, zásadní politicko-národnostní zlom neznamenal výraznou diskontinuitu v postavení lokálních politických elit, které si v obou maloměstech stále udržují politický (přímý v Brixenu pouze do konsolidace fašistické moci) a šířeji společenský vliv. Můžeme říci, že tak dochází spíše k určité redefinici jejich vlivu, nikoliv k jeho fatální ztrátě.

\section{Poděkování}

Studie byla podpořena v rámci Fondu pro podporu vědecké činnosti Filozofické fakulty Univerzity Palackého v Olomouci. 


\section{Prameny a literatura}

\section{Prameny}

SLA Bozen a), Südtiroler Landesarchiv Bozen. Familien- und Firmenarchiv Mallepell, Brixen. Position: 14, 1924-1948, Korrespondenz.

SLA Bozen b), Südtiroler Landesarchiv Bozen. Verfachbücher Brixen, 1528-1920 (818), Register: $1817-1920$.

SOkA Uherské Hradiště a), AM UH III, inv. č. 137, fond Fišerová - Nováková Marie, Ustanovení provisorním učitelem, skutečným učitelem a profesorem.

SOkA Uherské Hradiště b), AM UH III, inv. č. 120, fond Fišerová - Nováková Marie, Vysvědčení ze 4. a 5. roč. gymnázia.

SOkA Uherské Hradiště c), AM UH III, inv. č. 596, Náhrada škody Em. Fürstovi za vydrancování obchodu, úvěr pro živnostníky válkou poškozené (1919-1920).

SOkA Uherské Hradiště d), AM UH III, inv. č. 338, Naše Slovácko z 6. zář́i 1928, nekrolog Bohumila Fišera.

SOkA Uherské Hradiště e), AM UH, inv. č. N - 18, Nová Slovač, č. 3, 20. ledna 1906, s. 1.

SOkA Uherské Hradiště f), AM UH III, inv. č. 19, Kniha protokolů o sezeních obecního výboru, 23. 7. a 31. 7. 1912.

SOkA Uherské Hradiště g), AM UH III, kart. 1, inv. č. 1, Kronika Uherského Hradiště (1931-1933).

SOkA Uherské Hradiště h), AM UH III, inv. č. 582, Spořitelny a záložny (1870-1923).

SOkA Uherské Hradiště i), AM UH III, inv. č. 795, Volby do městského výboru a zastupitelstva (1900-1928).

SOkA Uherské Hradiště j), AM UH III, inv. č. 433, Zápisy městského výboru (29. 7. 1921, č. j. protokolu 3788)

SOkA Uherské Hradiště k), AM UH III, inv. č. 19, Zápisy městského zastupitelstva 1912-1925, karton 19.

SOkA Uherské Hradiště l), AM UH III, inv. č. 115, Živnostenský rejstř́ík královského města Uh. Hradiště (1907-1919).

\section{Literatura}

Alexander, Helmut (ed.) [2010]. Sigismund Waitz, Seelsorger, Theologe und Kirchenfürst. Innsbuck: Tyrolia Verlag.

Assecuranz-Compass, Band 1, Internationales Jahrbuch für Versicherungswesen, Wien 1921.

Austrier Blätter. Max Kurz Thurn Goldenstein Nachruf, č. 26, 1957, s. 312-313.

Bergmann, Ivan [2007]. Po stopách polozapomenutého architekta. Zvuk Zlínského kraje. jaro/léto 2007: 33-39.

Bösch, Adolf [1992]. In Lustenau, da zankten sich die „Alten“ und die „Neuen“. Ein Kapitel aus der Lustenauer Parteiengeschichte. Lustenau und seine Geschichte 3, Lustenau, s. 38-41.

Boelitz, Otto [1930]. Das Grenz- und Auslanddeutschtum, seine Geschichte und seine Bedeutung. München Berlin: Oldenbourg.

Bosworth, R. J. B. [2006]. Mussolini's Italy. Life under the Dictatorship 1915-1945. London: Penguin Books. Bozner Nachrichten. Die Bürgermeisterwahl in Brixen, 7. října 1913, s. 1.

BrixnerBote. Festabend zu Ehren des neuen Bürgermeisters, 22. března 1922, s. 1.

Brixener Chronik. 7. ŕíjna 1913, s. 2.

Brixener Chronik. 10. ŕíjna 1915, s. 4.

Brixener Chronik. 14. srpna 1915, s. 8.

Brixener Chronik. 29. května 1913, s. 3.

Brixener Chronik. Der Bürgemeister von Brixen Johann Stremitzer gestorben, 10. srpna 1915, s. 6.

Bruckmüller, Ernst [1990]. Herkunft und Selbstverständnis bürgerlicher Gruppierungen in der Habsburgermonarchie. Eine Einführung. In. Bruckmüller, Ernst - Döcker, Ulrike - Stekl, Hannes - Urbanitsch, Peter (ed.). Bürgertum in der Habsburgermonarchie 1. Wien - Köln - Weimar, s. 13-20.

Čerešňák, Bedřich [1971]. Třídní boje na jihovýchodní Moravě v letech 1918 až 1920. Jižní Morava 7: 5-18.

Čoupek, Jiří [1997]. Ing. František Beneš. Zpravodaj města Uherské Hradiště 7 (11): 14. 
Čoupek, Jiř́ [2000]. Ungarisch-Hradisch - Bürgertum und Stadtpolitik. In: Urbanitsch Peter - Stekl, Hannes (ed.). Kleinstadtbürgertum in der Habsburgermonarchie 1862-1914. Wien - Köln - Weimar, s. 355-381.

Deputato Otto Guggenberg. Parlamento italiano. Camera dei deputati. Portale storico [online]. Dostupné z: <https://storia.camera.it/deputato/otto-guggenberg-18870828> [cit. 12. 11. 2018].

Dokumentationsarchiv des österreichischen Widerstandes [1991]. Widerstand un Verfolgung in Salzburg 1934-1945. 2 Bd. Wien - Salzburg.

Dolomiten - Tagblatt der Südtiroler. Elmar Oberkofler, Tirols grösster Sagensammler, 21. května 1997.

Fasora, Lukáš [2005]. Sociální a profesní struktura brněnské komunální reprezentace v letech 1851-1904. Český časopis historický 103 (2): 354-356.

Fischnaler, Konrad [1929]. Innsbrucker Chronik II. Innsbruck: Vereinsbuchhandlung und Buchdruckerei.

Flachenecker, Helmut [1992]. Brixen und Eichstätt im Mittelalter. Zwei geistliche Städte im Vergleich. Der Schlern 66: 392-404.

Freund, Fritz [1911]. Das österreichische Abgeordnetenhaus. Ein biographisch-statistisches Handbuch, 1911-1917, XII. Legislaturperiode. Wien: Verlag Dr. Rudolf Ludwig.

Frie, Ewald [2004]. Das Deutsche Kaiserreich (Kontroversen um die Geschichte). Darmstadt: Wissenschaftliche Buchgesellschaft.

Fröschl, Gabriele [2000]. Wels - Im Schatten der Landeshauptstadt. In. Urbanitsch, Peter - Stekl, Hannes (ed.). Kleinstadtbürgertum in der Habsburgermonarchie 1862-1914. Wien - Köln - Weimar, s. 383-419.

Galusek, Anton [1879]. Die Gemeinde-Verwaltung der königl. Stadt Ung.-Hradisch von 1848 bis 1878, neblt einem Beitrage zur älteren Belchichte dieler königl. Stadt bis 1848. Ungarisch Hradisch.

Gaydosh, Brenda L. [2017]. Bernhard Lichtenberg. Roman Catholic Priest and Martyr of the Nazi Regime. London: Lexington Books.

Gelmi, Josef [2000]. Geschichte der Stadt Brixen. Brixen: Weger.

Gelmi, Josef [1998]. Geschichte der Diözesen Bozen-Brixen und Innsbruck. Bd. 5: Zeitgeschichte von 1919 bis heute. Kehl am Rhein.

Gentile, Emilio [2005]. Fascismo. Storia e interpretazioni. Roma - Bari: Editori Laterza.

Haid, Gerlinde [2004]. Volksmusik in Tirol im 18. und 19. Jahrhundert. In. Drexel, Kurt - Fink, Monika (ed.). Musikgeschichte Tirols II: Von der frühen Neuzeit bis zum Ende des 19. Jahrhunderts. SchlernSchriften, Bd. 322. Innsbruck: Wagner, s. 719-721.

Haas, Hanns [1990]. Postmeister, Wirt, Kramer, Brauer, Müller und Wundarzt. Trägerschichten und Organisationsformen des Liberalismus. Das Salzburger Beispiel - vom frühen Konstitucionalismus bis zum Kulturkampf. In. Bruckmüller, Ernst - Döcker, Ulrike - Stekl, Hannes - Urbanitsch, Peter (ed.). Bürgertum in der Habsburgermonarchie. Bd. 1. Wien - Köln - Weimar, s. 257-273.

Heiss, Hans [2004]. Das „lange“ 19. Jahrhundert. Brixen 1803-1918. In. Fuchs, Barbara - Heiss, Hans Milesi, Carlo - Pfeifer, Gustav (ed.). Brixen, Bd. 1. Die Geschichte. Bozen: Athesia Tappeiner Verlag, s. 201-236.

Heiss, Hans [1999]. Schwaighofer, Franz (1826-1891), Politiker und Färber. Österreichisches Biographisches Lexikon 1815-1950, Bd. 11 (Lfg 54). Wien: Verlag der Österreichischen Akademie der Wissenschaften, s. $415-416$.

Herrmann-Schneider, Hildegard [1995]. Jakob Schöpfer. Österreichisches Biographisches Lexikon (ÖBL) 1815-1950, Bd. 11 (Lfg 51). Wien: Verlag der Österreichischen Akademie der Wissenschaften, s. $108-109$.

Hobzová, Ludmila [1991]. Židé v Uherském Hradišti. Slovácké noviny 2 (48): 4.

Jablonka, Hans [1971]. Waitz, Bischof unter Kaiser und Hitler. Wien: Wiener Dom-Verlag.

Jacobeit, Wolfgang [1988]. Dorf und dörfliche Bevölkerung Deutschlands im bürgerlichen 19. Jahrhundert. In. Kocka, Jürgen (ed.). Bürgertum im 19. Jahrhundert. Deutschland im europäischen Vergleich, Bd. 2. München: Deutscher Taschenbuch Verlag, s. 315-339.

Jančář, Josef [1965]. Slovácké muzeum 1914-1964. Uherské Hradiště: Slovácké muzeum.

Jarušek, Robert [1934] (ed.). Uherské Hradiště město a okres. Národohospodářská propagace Československa. Řada A, svazek 11, s. 22-122.

Kasslatter, Sabina [1988]. Die Stadt Brixen von 1918 bis 1925: wirtschaftliche und soziale Anpassungsprobleme. Dipl.-Arb. Innsbruck.

Katholischen Sonntagsblätter 13, 1939, č. 7, s. 3. 
Kladiwa, Pavel [2004]. Obecní výbor Moravské Ostravy 1850-1918: komunální samospráva průmyslového města a její prèedstavitelé. Ostrava: Ostravská univerzita.

Klein, Kurt (ed.) [2016]. Historisches Ortslexikon. Statistische Dokumentation zur Bevölkerungs- und Siedlungsgeschichte. Südtirol. Datenbestand: 31. 8. 2016 [online]. Dostupné z: <https://www.oeaw .ac.at/vid/research/research-groups/demography-of-austria/historisches-ortslexikon> [cit. 22. 4. 2018].

Kocka, Jürgen [1989]. Bildungsbürgertum - Gesellschaftliche Formation oder Historikerkonstrukt ? In. Kocka, Jürgen (ed.). Bildungsbürgertum im 19. Jahrhundert, Bd. IV. Politischer Einfluß und gesellschaftliche Formation. Stuttgart: Klett-Cotta, s. 9-20.

Kogler, Nina [2010]. Sigismund Waitz - Bischof der Katholischen Frauenorganisation. In. Alexander, Helmut (ed.). Sigismund Waitz, Seelsorger, Theologe und Kirchenfürst. Innsbuck: Tyrolia Verlag, s. 293-330.

Königsrainer, Ulrike [1995]. Stadtbürgertum und Politik in Brixen zwischen 1861 und 1914. phil. Dipl. Arb., Wien.

Kriechbaumer, Robert [2006]. „Dieses Österreich retten. “Die Protokolle der Parteitage der Christlichsozialen Partei in der Ersten Republik. Wien: Böhlau Verlag.

Lechner, Stefan [2011]. Zwischen Brenner und Salurn: Die Grenzen des Faschismus in Südtirol. Geschichte und Region/Storia e regione 20: 50-65.

Leonardi, Andrea [1998]. Mobilità imprenditoriale e di capitale nella nascita e nello sviluppo dei „Kurorte“ austriaci nel secolo XIX. In. Fontana, Giovanni Luigi - Leonardi, Andrea - Trezzi, Luigi (ed.). Mobilità imprenditoriale e del lavoro nelle Alpi in età moderna e contemporanea. Milano: CUESP, s. 209-225.

MacNutt, Francis A. [2017]. Ein Geheimkämmerer am Hofe des Vatikan. Die Erinnerungen des Francis Augustus MacNutt 1863-1927. Stuttgart/Brixen: Belser/Weger.

Makariusová, Marie [2014]. Biografický slovník Českých zemí Fi-Fn̆, 17. sešit. Historický ústav Akademie věd České republiky. Praha: Academia.

Maliŕ, Jiří [2000]. K typu honoračního politika. Neformální osobní vazby a politická kariéra v 19. století. In. Marek, Pavel (ed.). Osobnost v politické straně. Sborník referátů z konference „Úloha osobností v dèjinách politických stran na území českých zemí a Československa v letech 1861-1999“. Olomouc: Moneta FM, s. 11-33.

Maliŕ, Jiří [2014]. Pokrokové hnutí na Moravě II. Vznik a vývoj moravské pokrokové strany. In. Maliř, Jiří (ed.). Občanská společnost na Moravě. Spolky, strany, elity. Brno: Matice Moravská, s. 415-450.

Malír, Jiří - Marek, Pavel a kol. [2005]. Politické strany. Vývoj politických stran a hnutí v českých zemích a Československu 1861-2004, I. díl 1861-1938. Brno: Doplněk.

Maliŕ, Jiří a kol. [2012]. Biografický slovník poslanců moravského zemského sněmu v letech 1861-1918. Brno: Centrum pro studium demokracie a kultury.

Maliř, Jiří [1978-1979]. Pokrokové hnutí na Moravě II. Vznik a vývoj moravské pokrokové strany. In. Sborník prací Filosofické fakulty brněnské university, 27-28 (C25-26), s. 99-129.

Meraner Zeitung. Der Kampf um Brixen, 7. listopadu 1913, s. 1.

Milesi, Carlo [2002]. L'amministrazione comunale di Bressanone negli anni 1918-1926. In. 50 anni Consiglio Comunale democraticamente eletto Brixen-Bressanone 1952-2002 [online]. Dostupné z: <http:// www.brixmedia.it/media/ed7b0ea8-43af-4ed9-9f21-589ee8ff3f5d/50-jahre-buch-bx.pdf > [cit. 11. 10. 2018].

Mock, Hubert [2004]. Übergänge. Brixen 1918-1945. In. Fuchs, Barbara - Heiss, Hans Milesi, Carlo Pfeifer, Gustav (ed.). Brixen, Bd. 1. Die Geschichte. Bozen: Athesia Tappeiner Verlag, s. 237-273.

Mock, Hubert [2017]. Wer war Francis MacNutt? Brixner 28: 32-36.

Mosser, Alois [1980]. Die Industrieaktiengesellschaft in Österreich 1880-1913. Versuch einer historischen Bilanz- und Betriebsanalyse. Studien zur Geschichte der österreichisch-ungarischen Monarchie 8, Wien: Österreichische Akademie der Wissenschaften.

Navrátil, Michal [1930]. Almanach československých právníků. Praha.

Novela k obecním zrrízením, č. 76/1919 Sb., 7. 2. 1919.

Omelková, Jana [2009]. Pohled do historie působení Židů v Uherském Hradišti. Slovácký deník 19 (11. 4. 2009): 12.

ÖBL. Österreichisches Biographisches Lexikon 1815-1950, Bd. 2 [1959]. Guggenberg zu Riedhofen, Athanasius von (1846-1920), Generalmajor und Abgeordneter. Wien: Verlag der Österreichischen Akademie der Wissenschaften, s. 105. 
Parschalk, Norbert [1999]. Die Stadtverwaltung Brixen 1918-1939. Geschichte und Region/Storia e regione 8: 105-130.

Pěkný, Tomáš [2001]. Historie Židů v Čechách a na Moravě. Praha: Sefer.

Rainer, Karl [2010]. Regionale Selbstverwaltung und Minderheitenpolitik. Das Fallbeispiel Südtirol. In. Vogt, Matthias Theodor - Sokol, Jan - Bingen, Dieter - Neyer, Jürgen - Albert Löhr (ed.). Minderheiten als Mehrwert. Frankfurt am Main: Peter Lang, s. 205-216.

Rája, Martin [2015]. V čele občanských elit: advokáti a společnost na Moravě v letech 1869-1914. Brno: Matice moravská.

Reulecke, Jürgen [1985]. Geschichte der Urbanisierung in Deutschland. Frankfurt am Main.

Řád volení v obcích republiky Československé, č. 75/1919 Sb., 31. 1. 1919.

Segatori, Roberto [2003]. I sindaci. Storia e sociologia dellamministrazione locale in Italia dall'Unità a oggi. Roma: Donzelli Editore.

Schober, Richard [1993]. Politischer Katholizismus am Fall-beispiel Deutschtirols. Studi Trentini di Scienze Storiche 72 (4): 601-634.

Schumann, Hans-Gerd [1983]. Die soziale und politische Funktion lokaler Eliten. Methodologische Anmerkungen zum Forschungsstand. In. Kirchgässner, Bernhard - Schadt, Jörg (ed.). Kommunale Selbstverwaltung - Idee und Wirklichkeit. Sigmaringen, s. 30-38.

Sparber, Anselm [1957]. Brixens Entwicklung seit 1803. Der Schlern 31: 121-134.

Spezialortsrepertorium der österreichischen Länder. X, Spezialortsrepertorium von Mähren. Bearbeitet auf Grund der Ergebnisse der Volkszählung vom 31. Dezember 1910, Wien 1910.

Stekl, Hannes - Urbanitsch, Peter [2000]. Zusammenfassung: Kleinstadt und Bürgertum in Cisleithanien 1862-1914. In. Stekl, Hannes - Urbanitsch, Peter (ed.). Kleinstadtbürgertum in der Habsburgermonarchie 1862-1914. Bürgertum in der Habsburgermonarchie IX., Wien - Köln - Weimar 2000, s. 465-494.

Steuerer, Leopold [1980]. Südtirol zwischen Rom und Berlin. 1919-1939. Wien: Europaverlag.

Strmiska, Maxmilián [1998]. Regionální strany a stranické systémy. Brno: CDK.

Tethal, Vladimír [2004]. Farnost sv. Františka Xaverského v Uherském Hradišti v letech 1778-1918. Slovácko 46: 209-232.

Tomeš, Josef [2013]. Česká strana státoprávně pokroková (1908-1918). Dizertační práce, Praha: FF UK.

Tweraser, Kurt [1980]. Der Linzer Gemeinderat 1880-1914. Glanz und Elend bürgerlicher Herrschaft. In. Historisches Jahrbuch der Stadt Linz, s. 293-341 [online]. Dostupné z: <https://www.ooegeschichte.at> [cit. 15. 11.2018].

Verbík, Antonín - Zemek, Metoděj a kol. [1981]. Uherské Hradiště - dějiny města. Brno: Nakl. Blok.

Volksbote. 16. února 1928, s. 9.

Weiser, Tomáš [2001]. Návrh tezí k teoretické a metodologické inovaci oboru „sociální dějiny“"v české historiografii. Studie k sociálním dějinám 6, Kutná Hora - Praha - Opava, s. 9-21.

Zapletal, Jan - Zapletalová, Markéta [2019]. Nové politické elity maloměst na přelomu 19. a 20. století. Český časopis historický 117 (2): 347-380.

Jan Zapletal je absolvent Masarykovy Univerzity v Brně. V současné době pưsobí jako učitel, je členem zastupitelstva města Uherské Hradiště a externím vědeckým spolupracovníkem na Filozofické fakultè Univerzity Palackého v Olomouci.

Markéta Zapletalová pưsobí jako odborná asistentka na Katedře politologie a evropských studií Filozofické fakulty Univerzity Palackého v Olomouci. 